\title{
The First of That Name
}

\author{
Regina Buccola
}

How comforting it must be for you to have a mother who lost her head long before she could assign one to you.

Daughter of a whore, you had no need to whore yourself to any,

though some say you tried many, found all of them wanting in your eyes, or those of your wise councilors, and thus you reign, sole, anointed Elizabeth, the first of that name.

Have you forgot me? Though you never knew me, certain it is you knew of me. Every time you walk with regal step beneath those carved Tudor roses

I should be twinned to your thoughts, the first rose of that branch, thornless, whose blooming made your stock possible: Elizabeth Tudor, first of that name.

Named for my mother, whored to a king (as some would have it) whose brother-king asked her to twist me to him, niece-wife; she saved me by binding me to his thorn. 